\title{
Process Knowledge Summary Report for Materials and Fuels Complex Contact- Handled Transuranic Debris Waste
}

R. P. Grant

P. J. Crane

S. Butler

M. A. Henry

February 2010

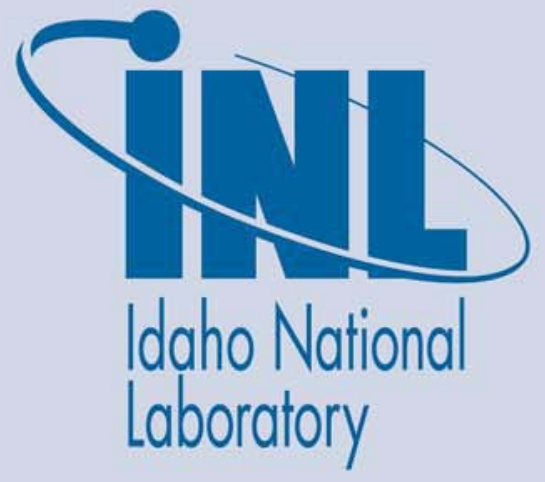

The INL is a U.S. Department of Energy National Laboratory operated by Battelle Energy Alliance 
INL/EXT-10-17600

\title{
Process Knowledge Summary Report for Materials and Fuels Complex Contact-Handled Transuranic Debris Waste
}

\author{
R. P. Grant \\ P. J. Crane \\ S. Butler \\ M. A. Henry
}

February 2010

\author{
Idaho National Laboratory \\ Idaho Falls, Idaho 83415 \\ http://www.inl.gov
}

\author{
Prepared for the \\ U.S. Department of Energy \\ Office of Nuclear Energy \\ Under DOE Idaho Operations Office \\ Contract DE-AC07-05ID14517
}




\section{ABSTRACT}

This Process Knowledge Summary Report summarizes the information collected to satisfy the transportation and waste acceptance requirements for the transfer of transuranic (TRU) waste between the Materials and Fuels Complex (MFC) and the Advanced Mixed Waste Treatment Project (AMWTP). The information collected includes documentation that addresses the requirements for AMWTP $^{(23)}$ and the applicable portion of their Resource Conservation and Recovery Act permits for receipt and treatment of TRU debris waste in AMWTP.

This report has been prepared for contact-handled TRU debris waste generated by the Idaho National Laboratory at MFC. The TRU debris waste will be shipped to AMWTP for purposes of supercompaction.

This Process Knowledge Summary Report includes information regarding, but not limited to, the generation process, the physical form, radiological characteristics, and chemical contaminants of the TRU debris waste, prohibited items, and packaging configuration. This report, along with the referenced supporting documents, will create a defensible and auditable record for waste originating from MFC. 


\section{CONTENTS}

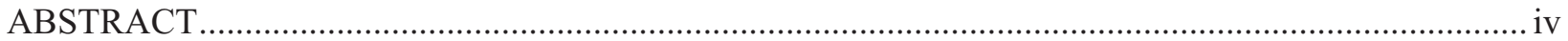

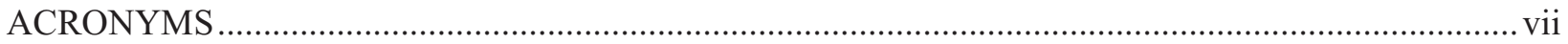

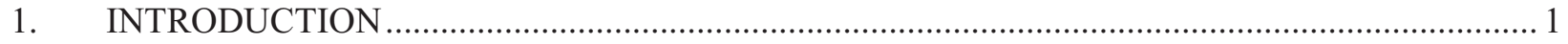

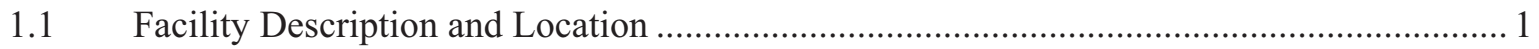

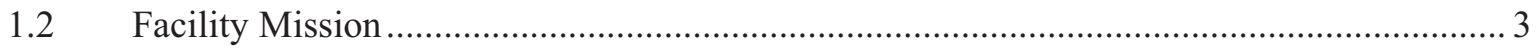

2. PROCESS KNOWLEDGE DATA AND INFORMATION ................................................... 4

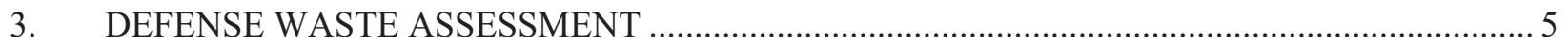

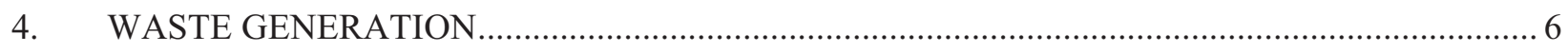

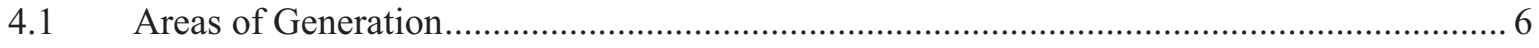

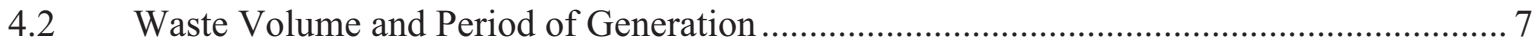

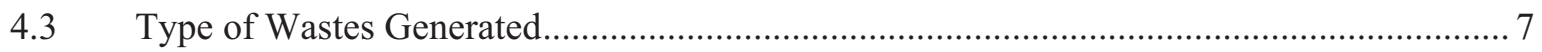

4.4 Description of Processes that Generate Waste …....................................................... 8

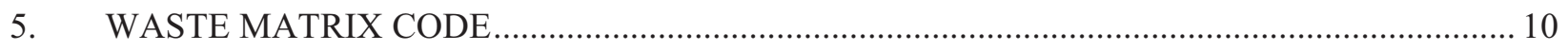

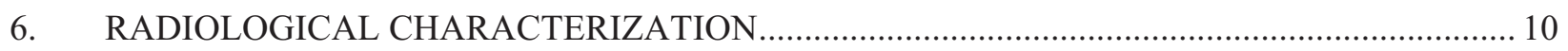

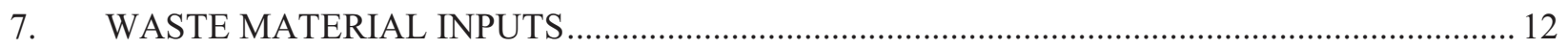

8. RESOURCE CONSERVATION AND RECOVERY ACT DETERMINATIONS ...................... 13

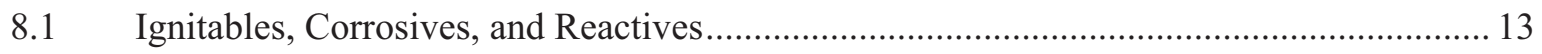

8.2 Toxicity Characteristic Leachate Procedure ................................................................ 13

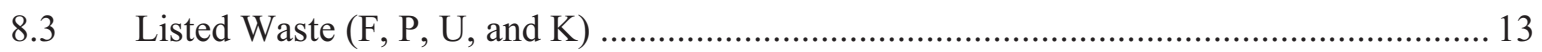

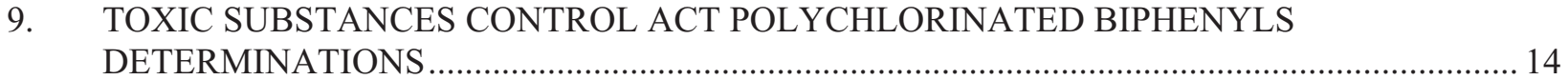

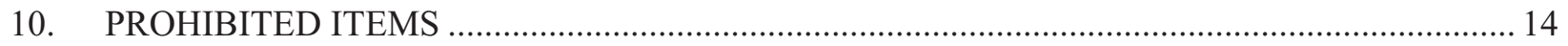

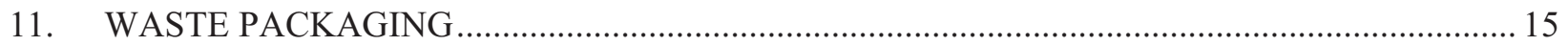

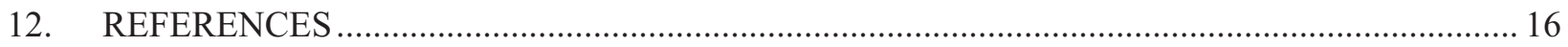




\section{FIGURE}

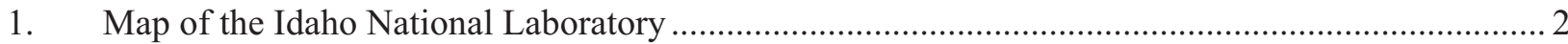

\section{TABLES}

1. General description of debris waste by generation area and dates, with corresponding

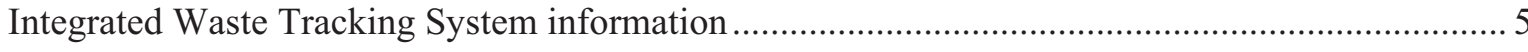

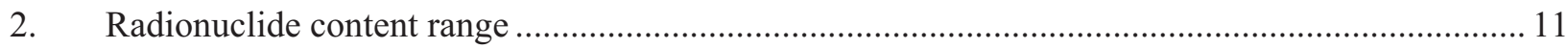

3. Waste chemicals/constituents in Materials and Fuels Complex transuranic debris ....................... 12 


\section{ACRONYMS}

AFCI Advanced Fuel Cycle Initiative

AL Analytical Laboratory

AMWTP Advanced Mixed Waste Treatment Project

CFR Code of Federal Regulations

DOE U.S. Department of Energy

FCF Fuel Conditioning Facility

FMF Fuel Manufacturing Facility

HEPA high-efficiency particulate air

HWN hazardous waste number

INL Idaho National Laboratory

IWTS Integrated Waste Tracking System

MFC Materials and Fuels Complex

$\mathrm{nCi} / \mathrm{g} \quad$ nanocuries per gram

NWPA Nuclear Waste Policy Act of 1982

RCRA Resource Conservation and Recovery Act

TRU transuranic

WIPP Waste Isolation Pilot Plant

WSP Waste stream profile 


\section{Process Knowledge Summary Report for Materials and Fuels Complex Contact-Handled Transuranic Debris Waste}

\section{INTRODUCTION}

This Process Knowledge Summary Report summarizes information collected to satisfy the transportation and waste acceptance requirements for the transfer of contact-handled transuranic (TRU) debris waste between the Materials and Fuels Complex (MFC) and the Advanced Mixed Waste Treatment Project (AMWTP) ${ }^{(23)}$ for the purposes of storage and subsequent supercompaction. The information collected includes documentation that addresses the requirements for AMWTP and applicable sections of their Resource Conservation and Recovery Act (RCRA) permits.

The MFC TRU debris waste is generated in support of national defense and is considered to be a defense-related waste per the Nuclear Waste Policy Act of 1982 (NWPA). Non-defense related debris waste is not intentionally mixed with defense-related debris waste. Waste that does not meet the definition of defense waste per NWPA will not be shipped to AMWTP.

AMWTP will be notified in writing when any of the following occur:

- $\quad$ New waste is proposed to be shipped to AMWTP

- A change to the generating process takes place

- New hazardous constituents are introduced to the waste

- $\quad$ A change in hazardous waste numbers (HWNs)

- Changes occur in the polychlorinated biphenyls status

- $\quad$ Changes in the radiological composition from that previously identified.

This information will be reviewed to determine if a revision to this document or the AMWTP waste stream profile form (Form-1687) will be required. In addition, this document will be reviewed on an annual basis to ensure up-to-date information is provided to AMWTP.

\subsection{Facility Description and Location}

MFC (formerly known as Argonne National Laboratory-West) is a Department of Energy (DOE) facility located near the southeast corner of the Idaho National Laboratory (INL) Site, about 3 miles north of U.S. Highway 20. The MFC has been serving the INL and DOE complex for more than 50 years. MFC includes facilities for processing, examining, characterizing, and analyzing radioactive materials. Figure 1 provides a map that identifies the general location of MFC. ${ }^{(1)}$

The principal, currently operating facilities at MFC are the Analytical Laboratory (AL), Fuel Conditioning Facility, Fuel Manufacturing Facility (FMF), Hot Fuel Examination Facility, and the Space and Security Power Systems Facility. This document only addresses TRU debris waste generated by operations in AL (Building 752) and FMF (Building 704). 


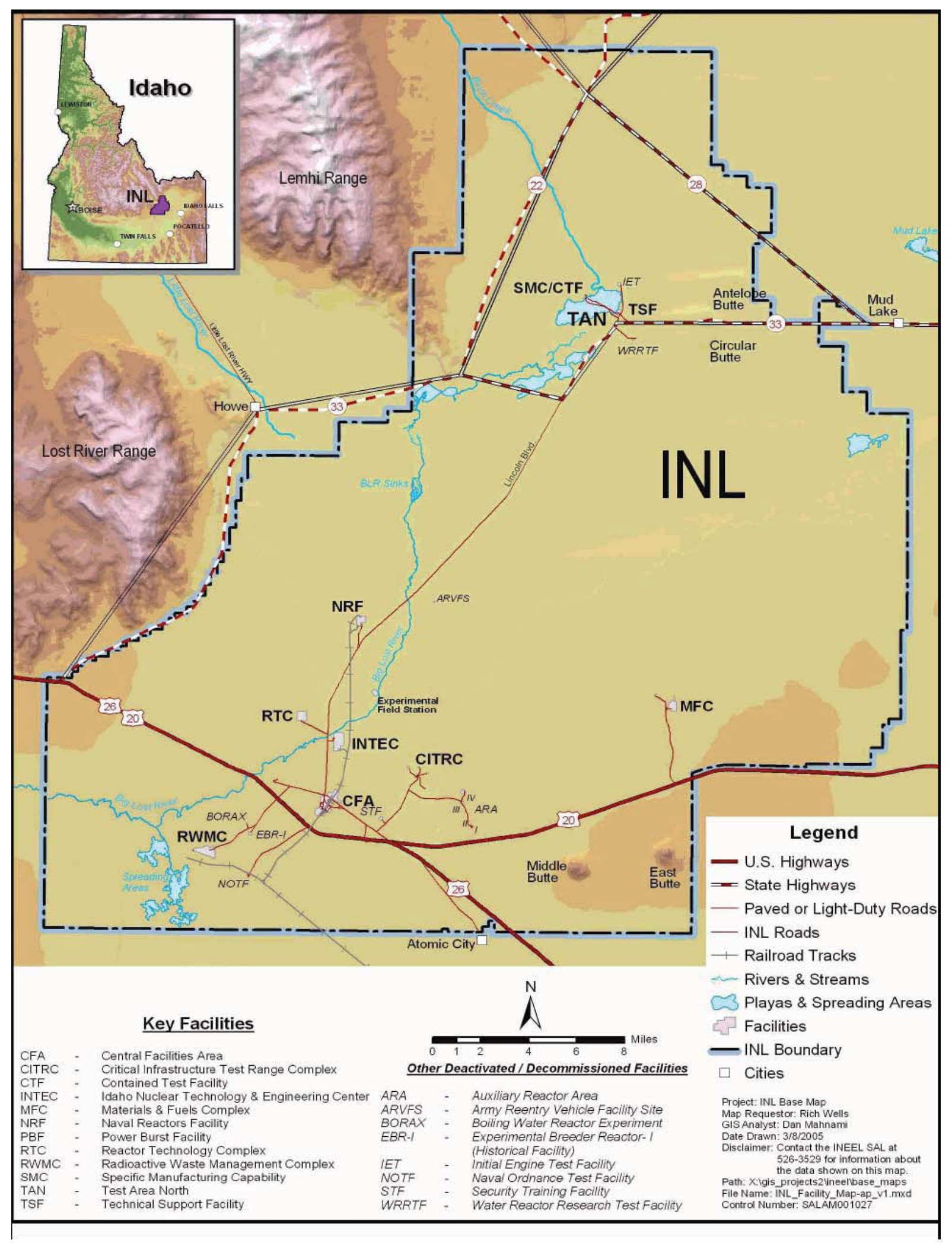

Figure 1. Map of the Idaho National Laboratory. 
Building 752 (AL) is a Hazard Category 3 non-reactor nuclear facility, was constructed in the late 1950s, and has been operational for approximately 50 years with a number of significant facility upgrades completed throughout the years. AL is housed within the Laboratory and Office Building (Building 752). AL provides a variety of chemical, physical, radiological, and nondestructive assay analysis services and conducts applied research and engineering development activities in support of nuclear fuel development, waste management, environmental, and other programs at MFC and INL through a broad range of analytical chemistry capabilities. ${ }^{(1)}$

Building 704 (FMF) was designed and built for fabricating metal fuels for the Experimental Breeder Reactor-II, other fuel casting processes, and sample preparation conducted for reactor fuels research projects for DOE (such as the Advanced Fuel Cycle Initiative [AFCI]). ${ }^{(2)}$ FMF is used for fabricating fuels or material samples containing uranium, plutonium, americium, neptunium, and other TRU isotopes. Projects conducted through FMF also can use other facilities with additional capabilities (such as the Fuels and Applied Sciences Building [MFC-787]), which was formerly known as the Fuel Assembly and Storage Building.

1. Generation location:

Materials Fuel Complex

Idaho National Laboratory

Scoville, Idaho

Environmental Protection Agency ID ID4890008952

2. Storage location:

Materials Fuel Complex

Idaho National Laboratory

Scoville, Idaho

Environmental Protection Agency ID ID4890008952

3. Facilities where TRU waste was generated:

Buildings 704 and 752 at MFC.

\subsection{Facility Mission}

MFC's current mission is to lead development of advanced, sustainable nuclear power systems in the United States. The work centers on the AFCI, Generation IV Nuclear Reactor Program, and Space Nuclear Program initiatives. ${ }^{(2)}$ MFC's capabilities encompass the entire nuclear fuel cycle and include nuclear fuel development, spent fuel disposition technology development, liquid metal technology, post-irradiation examination, waste and nuclear material characterization, nuclear waste stabilization development, and development of dry, interim storage for spent fuel and other highly radioactive materials. MFC has a unique suite of nuclear, radiological, and industrial facilities. MFC receives materials from a variety of defense and civilian programs across the DOE complex. ${ }^{(3)}$

The previous MFC facility mission included development of advanced reactor concepts and fuel cycle process development, including fabrication of fuel and fuel rods, examination and testing of fuel and fuel materials, and development of homeland security research, decontamination and decommissioning technologies, and reactor and fuel cycle safety. ${ }^{(1)}$ 


\section{PROCESS KNOWLEDGE DATA AND INFORMATION}

Waste characterization and container information are documented by completing INL Integrated Waste Tracking System (IWTS) material and container profiles. Process knowledge data, analytical results, and container inventory are used to profile the waste stream and are recorded in IWTS. ${ }^{(4)}$

When analytical results are used to characterize waste, the results are compiled and recorded in an engineering design file or and engineering calculation and analysis report. Assay information is based on material balance, smear analysis, and destructive or non-destructive assay data. Radiological surveys and sample results are used to provide verification of waste stream characteristics and identify and quantify the radionuclide content. Curie content of TRU waste is determined through radiological smear analysis, nondestructive assay testing, or AL methods. ${ }^{(1,4)}$

HWNs and chemical constituents associated with MFC debris waste are assigned/identified based on process knowledge (e.g., review of material inputs, processes generating the waste, and chemicals used) and analytical results when available. Sampling and analyses, if required, are performed in accordance with SW-846, "Test Methods for Evaluating Solid Waste, Physical/Chemical Methods," or by specific approved alternate methods. ${ }^{(1,4)}$

The contents of waste containers are inventoried, loaded with second operator verification, and documented. The characterization and management of TRU wastes generated at MFC facilities are certified through use of formal controls and documentation (e.g., IWTS, forms, including INL Form 435.83, "Idaho National Laboratory Transuranic Waste Disposal (Checklist)," Form 412.09, "Waste-Container Inventory Logsheet," and TEM-10200-1, "Engineering Calculation and Analysis Report"). ${ }^{(1,5)}$

- Low-level waste and mixed low-level waste will not be included in TRU debris waste shipped to AMWTP.

- $\quad$ Polychlorinated biphenyl waste (if found or identified) will not be included in TRU debris waste shipped to AMWTP.

- $\quad$ Only waste that is greater than $100 \mathrm{nCi} / \mathrm{gm}$ will be shipped to AMWTP.

- $\quad$ Only waste generated under up-to-date IWTS profiles identified in Table 1 will be shipped to AMWTP.

- $\quad$ Some containers of TRU debris waste may contain less than 50\% non-debris waste. Non-debris waste generated within gloveboxes/hot cells from the sampling/testing of material that meets (or would meet) the definition of debris waste per 40 CFR 268.2 will be found in debris waste containers. For example, absorbed residual liquids associated with the testing of materials/fuels that meet the definition of debris may be placed into a debris waste container. In addition non-debris waste co-generated with debris (e.g., less than $60 \mathrm{~mm}$ co-generated with greater than $60 \mathrm{~mm}$ ) also may be managed within debris containers as long as the non-debris comprises less than $50 \%$ of the overall volume within the debris container.

- $\quad$ Defense and non-defense wastes are not intentionally mixed within TRU debris waste shipped to AMWTP. Defense and non-defense related waste that is not inherently comingled at the point of generation is segregated and managed separately. ${ }^{(3,6)}$ 
Table 1. General description of debris waste by generation area and dates, with corresponding Integrated Waste Tracking System information. ${ }^{(7,8,9,10,11,12,13,14,15,38,39)}$

\begin{tabular}{|l|c|c|c|}
\hline \multicolumn{1}{|c|}{ General Description } & Generation Area & $\begin{array}{c}\text { IWTS MP } \\
\text { Number }\end{array}$ & IWTS Dates \\
\hline FMF TRU Debris & FMF, Building 704 & $5419 \mathrm{~N} . \mathrm{R} 1^{(12)}$ & $9 / 29 / 09-$ current \\
\hline Building 752 TRU & AL, Building 752 & $3526^{(10)}$ & $4 / 1 / 99-$ inactive \\
Debris Waste from AL & & $3527^{(7)}$ & $4 / 1 / 199-$ inactive \\
Gloveboxes/Hot Cells & & $3527 . R 1^{(39)}$ & $9 / 29 / 09-$ current \\
& & $5274 \mathrm{~N}^{(8)}$ & $3 / 9 / 07-$ inactive \\
& & $5274 \mathrm{~N} \cdot 1^{(38)}$ & $9 / 29 / 09-$ current \\
& & $3657 \mathrm{P}^{(11)}$ & $12 / 3 / 02-$ current \\
& & ANL503T $^{(9)}$ & $2 / 18 / 98-$ current \\
& & ANL505T $^{(15)}$ & $2 / 18 / 98-$ inactive \\
& & $5185 \mathrm{~N}^{(13)}$ & $1 / 10 / 07-$ current \\
& & ANL142T $^{(14)}$ & $2 / 13 / 98-$ inactive \\
\hline
\end{tabular}

\section{DEFENSE WASTE ASSESSMENT}

The Waste Isolation Pilot Plant (WIPP) Waste Acceptance Criteria requires generator sites to use acceptable knowledge to determine if the TRU waste streams to be disposed of at WIPP meet the definition of TRU "defense" waste. Based on guidance from the DOE, TRU waste is eligible for disposal at WIPP if it has been generated in whole or part by one of the atomic energy defense activities listed in Section 10101(3) of NWPA. To receive waste at AMWTP acceptable knowledge or process knowledge can be used to satisfy the AMWTP waste acceptance criteria.

MFC debris waste is generated from a variety of activities conducted in laboratory hoods, gloveboxes, and hot cells associated with processing of radioisotopes in development of nuclear fuel, spent fuel disposition technology, liquid metal technology, nuclear waste stabilization, and new storage technologies for spent fuel and highly radioactive materials. In addition, TRU debris waste also is generated within gloveboxes from laboratory support for waste and nuclear material characterization via sample preparation and analyses. Debris waste generated within these gloveboxes is inherently commingled. This waste meets the definition of TRU waste in that it has been generated in whole or part by one of the activities identified within NWPA. ${ }^{(3,6)}$

The WIPP Land Withdrawal Act prohibits disposal of spent nuclear fuel and high-level waste, as defined by NWPA, at the WIPP facility. According to NWPA, spent nuclear fuel is "fuel that has been withdrawn from a nuclear reactor following irradiation, the constituent elements of which have not been separated by reprocessing." High-level waste is defined by NWPA as "the highly radioactive material resulting from the reprocessing of spent nuclear fuel, including liquid waste produced directly in reprocessing and any solid material derived from such liquid waste that contains fission products in sufficient concentrations, and other highly radioactive material that the Commission, consistent with existing law, determines by rule requires permanent isolation." Processing of spent fuel materials is not conducted in the AL or Casting Laboratory. While analytical support is provided for irradiated sample materials, the material does not consist of intact fuel elements, and fuel elements are not managed in these facilities. ${ }^{(1,3)}$ Therefore, the waste is not spent nuclear fuel or high-level waste. 
Based on a review of the waste generating processes, the contact-handled TRU debris waste generated at MFC and targeted for shipment to AMWTP has been determined to be defense-related and eligible for disposal at the WIPP facility.

Non-defense related debris waste is not intentionally mixed with defense-related debris waste. Waste that can be managed separately that does not meet the definition of defense waste per NWPA will not be shipped to AMWTP.

\section{WASTE GENERATION}

MFC TRU debris waste is generated from a variety of activities associated with the processing of radioisotopes in the following processes:

- $\quad$ Development of nuclear fuel, spent fuel disposition technology, liquid metal technology, nuclear waste stabilization, and new storage technologies for spent fuel and highly radioactive materials

- Operations conducted in Buildings 752 and 704 in support of research and development and waste and nuclear material characterization. Capabilities include sample preparation and analyses (chemical and radiological), plutonium alloy casting operations, development and fabrication of experimental waste forms, waste treatment, and spent fuel chemistry.

The TRU debris waste addressed in this report is generated in miscellaneous actinide fuel experiments or fabrication and sample preparation and analysis conducted in the AL and FMF laboratory hoods, gloveboxes, hot cells and maintenance activities conducted in Buildings 752 and 704 . Processes and types of debris generated are the same regardless of where the processing occurs: laboratory hoods are used for materials not requiring handling in gloveboxes or hot cells due to the level of radioactivity. Analytical methods include, but are not limited to, examination of plutonium-bearing fuel samples, testing fuel samples, spectrometry, and transmutation of fuels. Waste includes TRU debris waste and small amounts of non-debris waste generated during handling of samples (e.g., legacy waste containers and testing materials/fuels that meet the definition of debris), decontamination and maintenance of the gloveboxes/hot cells, and so forth. ${ }^{(7,8,9,10,11,12,13,14,15,38,39)}$

Examples of past debris waste generating programs are casting of metallic alloy test specimens from alloy fuel materials for the Integral Fast Reactor ${ }^{(4,6,11,13,14)}$; development and fabrication of experimental fuel materials and miscellaneous actinide fuel experiments; fabrication and handling of fuel consisting of americium, uranium, and plutonium alloyed with zirconium for the AFCI program; and the Accelerator Transmutation of Waste project. ${ }^{(6,17,18,19,20,22)}$

A general description of debris waste by generation area and dates, with corresponding IWTS waste material profiles is provided in Table 1. Only waste associated with IWTS waste material profiles identified in Table 1 is accepted at AMWTP for supercompaction.

\subsection{Areas of Generation}

The primary areas of waste generation are laboratory hoods, gloveboxes, and hot cells located in Buildings 752 (AL) and 704 (FMF). TRU debris waste also may be generated during waste handling and maintenance activities. 


\subsection{Waste Volume and Period of Generation}

An estimated sixty 55-gal drums of TRU debris currently stored at MFC are anticipated to be shipped to AMWTP for supercompaction for shipment to WIPP. Future TRU waste generation at MFC is highly dependent on project activities but typically averages from six to eighteen 55-gallon drums per year.

\subsection{Type of Wastes Generated}

TRU heterogeneous debris waste is generated from MFC laboratory hood, glovebox, and hot cell operations conducted in Buildings 752 and 704. The activities that generate the various types of debris that could be found in TRU debris shipped to AMWTP are identified in section 4.3.4.

The type of heterogeneous debris waste generated may vary from container to container; however, each container will contain at least $50 \%$ by volume TRU debris. The various debris waste generated from MFC programs and maintenance in Buildings 752 and 704 includes items such as laboratory equipment (e.g., press [fluid removed], electric saw, hacksaw and blades, welder controllers [no RCRA metals], tool boxes, hand tools, sonic sifter, profilometer, sample cabinet, metal files, grinder motors, poly reservoirs, pump, thermocouple wire, various types of wire [e.g., copper and steel], aluminum metal, steel, stone and glass polishing plates, scales, feed material transfer containers), miscellaneous laboratory ware (e.g., beakers, polyethylene bottles, glass, one-pint cans containing crushed glass or combustibles, aluminum and tin foil, sponges, and pipette tips), various sized paint cans (e.g., one-pint or one-gallon), paper, polyvinyl chloride bags, polyethylene bags and materials, cloth rags, terri-towels, glove port rings, nylon gloveport blanks, O-rings, wire brushes, neoprene gloves, personnel protection equipment, including Tyvek coveralls, booties, nitrile and leather gloves, leaded gloves, and thermal gloves, small aluminum cans containing laboratory glassware, graphite crucibles, high-efficiency particulate air filters with wood and metal frames, pre-filters, filter media and wood, rubber tubing, piping, miscellaneous metal pieces, and asbestos floor tile and insulation. . $^{7,8,9,10,11,12,13,14,15,38,39)}$

Legacy debris waste containers may contain less than $50 \%$ by volume non-debris as a result of legacy operations. Examples of non-debris legacy waste that may be included into legacy debris waste containers includes absorbed liquids (including fuels dissolved in acids that have been neutralized and solidified with absorbents such as Aquaset II, kitty litter, and diatomaceous earth), oils from pumps or other equipment solidified with absorbent (Petroset II), dissolved/solidified samples, and mop and paint scraping waste (e.g., cadmium, and immobilized particulates containing RCRA metals [cadmium, chromium, and lead]). ${ }^{(7,8,9,10,11,12,13,14,15,18,22)}$

Debris waste generated after 2010 only will include non-debris waste if the non-debris is less than $50 \%$ the overall volume of waste placed in the debris container and was either co-generated (e.g., less than $60 \mathrm{~mm}$ co-generated with greater than $60 \mathrm{~mm}$ ) or was generated as a result of testing material/fuels that would (or could) meet the definition of debris waste as defined in 40 CFR 268.2. Non-debris material/waste other than that noted above will be segregated from debris waste. ${ }^{(23)}$

Any liquids generated as a result of the above operations are neutralized, if corrosive, and solidified/absorbed through the addition of absorbent (i.e., Aquaset II, Petroset II, kitty litter, or diatomaceous earth) in small (less than 4-L) polyethylene bottles; small quantities of residual liquids associated with debris waste that are treated with the above absorbents may be found within debris waste containers. ${ }^{(5,25,36)}$ 


\subsection{Description of Processes that Generate Waste}

MFC TRU debris waste is generated from laboratory hoods, gloveboxes, and hot cells associated with research and development experiments and AL operations conducted in Buildings 752 and 704. These operations include plutonium-alloy casting operations; development, fabrication, and testing of experimental fuels and waste forms; and associated laboratory activities, including chemical and radiological analyses and spent fuel chemistry.

The following is a summary of the generation processes for Buildings 752 and 704 as a result of providing laboratory support and conducting maintenance activities associated with radioisotope development for nuclear fuel, spent fuel disposition technology, liquid metal technology, nuclear waste stabilization, and new storage technologies for spent fuel and highly radioactive materials.

\subsubsection{Building 752 Analytical Laboratory}

The AL provides support of MFC programs in the areas of sampling and analyses (e.g., metal and radioisotopic) and waste characterization. MFC TRU debris waste is generated in AL through a number of experimental activities conducted in laboratory hoods, gloveboxes, and hot cells, along with analytical sample applications and preparation and testing of waste forms. Debris waste is generated in a number of AL laboratory hoods, AL Hot Cells, and in four AL gloveboxes (i.e., the alpha, waste form testing, special projects, and casting laboratory gloveboxes). Remote-handled debris is segregated from contact-handled waste in the generating process areas by determining the level of radioactivity. ${ }^{(9,11,15)}$

The AL provides chemical analyses and radiological assay of materials from a variety of fuel debris sources: spent fuel and sodium/water characterization, sample analysis for the Fuel Conditioning Facility (FCF, MFC-765) electrorefining process and from non-MFC DOE facilities for the purposes of determining radioisotopic/metal composition. The AL sample fuel debris undergoes various experiments at MFC (see Section 4) and the resulting material is subject to laboratory analysis. The AL analysis provides information to support spent fuel conditioning operations, including the electrorefining process salts and final form ceramic and metal waste forms. The AL also receives fuel related debris materials from non-MFC DOE facilities for the purposes of determining radioisotopic/metal composition. ${ }^{(2,3,6,17,18}$ $19,20,21,22)$ The fuel debris characterization process consists of analyzing waste forms (e.g., oxidized WG$\mathrm{Pu}$, oxidized actinides) to determine impurities in the waste forms to facilitate purification. Sample and analysis waste is managed as transuranic when sample results determine that the waste TRU content exceeds $100 \mathrm{nCi} /$ gram. This electrorefining process consists of fuel dissolution in a molten salt bath and collection of recovered uranium on a cathode which is then processed into uranium ingots. Waste from sample analysis, when dispositioned by the AL, is managed as described in the IWTS Material and Container Profiles. . $, 8,9,10,11,12,13,14,15,38,39)$ Various TRU debris waste (see Section 4.3) are generated from the activities described in the following paragraphs.

Alpha glovebox operations consist of sample preparation and analysis primarily in support of Hot Fuel Examination Facility and Fuel Conditioning Facility hot cell operations, as well as other DOE sites such as Los Alamos National Laboratory. Operations in the alpha glovebox consist of fuel materials and cladding sample dissolution in hydrochloric, nitric, or hydrofluoric acid for radionuclide separations or

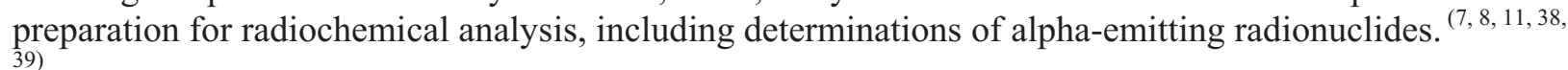

The waste form testing glovebox is used for sample preparation and mounting of plutonium-containing waste forms, including cutting, grinding, and polishing activities. This glovebox also is equipped to manufacture small-scale quantities of experimental waste forms or preparation and testing plutonium-bearing fuel samples. ${ }^{(7,8,11,38,39)}$ 
The special projects glovebox is used for preparation and testing of plutonium -containing waste forms, testing of material for thermal characterization, and other analytical sample applications. Fuels cladding chemical interaction studies (such as thermal analysis) are performed in the AL on the test specimens produced in other areas. Samples are heated in a furnace and vaporized with a laser and resulting vapors are analyzed. Special projects are conducted in this glovebox in support of the AFCI operations and other programmatic work. ${ }^{(7,8,911,15,38,39)}$

The casting laboratory glovebox is used for testing plutonium-containing waste forms, preparation of plutonium -bearing fuel samples, and manufacture of small-scale quantities of experimental waste forms in support of development and fabrication of experimental fuel materials. Capabilities include fuel

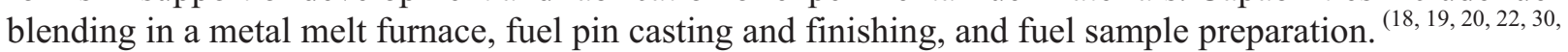
31)

Several analytical laboratory hoods/bench tops and hot cells also are located in the AL and are used in performance of the same processes described for the above gloveboxes, but for material with radioisotopic levels conducive to handling in the hoods or that require remote handling. ${ }^{(28)}$

TRU waste from the various gloveboxes is often packaged in a single drum because waste materials from laboratory operations are accumulated in gloveboxes and bagged out in campaign fashion. $(7,21,26,27)$

Debris waste (e.g., glassware, pipettes, and plastics) is generated during preparation and dissolution of samples, periodic decontamination of gloveboxes, installation or change out of glovebox gloves, and laboratory hood, glovebox, and hot cell maintenance activities. ${ }^{(9,11,15)}$

Debris waste generated after 2010 will only include non-debris waste if the non-debris is less than $50 \%$ the overall volume of waste placed in the debris container and was either co-generated (e.g., less than $60 \mathrm{~mm}$ co-generated with greater than $60 \mathrm{~mm}$ ) or was generated as a result of testing material/fuels that would (or could) meet the definition of debris waste as defined in 40 CFR 268.2. Non-debris material/waste other than that noted above will be segregated from debris waste. ${ }^{(11,12,13,38,39)}$

Maintenance and other activities (including refurbishment of the laboratory hot cells) also generate debris waste such as leaded glovebox gloves, high-efficiency particulate air filters, cadmium contaminated waste, and immobilized particulates or solutions containing RCRA metals (cadmium, chromium and lead) generated during cell and glovebox cleaning. $(9,13,14,15,38,39)$ Solutions consist of Blue Windex, Fantastik, All Purpose Cleaner, Radiacwash I or Radiacwash II poured or sprayed onto cloth. ${ }^{32}$, $33,34,35,39)$

\subsubsection{Building 704 Fuel Manufacturing Facility}

FMF consists of two gloveboxes used for fabrication of experimental fuels and preparation of actinide fuel experiments and samples for programs sponsored by DOE. Activities include actinide fuel casting/alloying and sample preparation for metal fuels for reactors such as the Experimental Breeder Reactor-II and programs in support of AFCI. Additionally, fuel casting processes for reactor fuels research projects are conducted in Building 704 as directed by DOE. ${ }^{(1)}$

TRU debris waste is generated during fuel casting processes and fuel pin sample preparation conducted for AFCI in FMF gloveboxes. ${ }^{(2)}$ The waste consists of solid fuel fabrication and sample waste contaminated with TRU isotopes originating in experimental fuels consisting primarily of alloys of zirconium, uranium, and plutonium..$^{(12)}$ 
Debris waste generated after 2010 will only include non-debris waste if the non-debris is less than $50 \%$ the overall volume of waste placed in the debris container and was either co-generated (e.g., less than $60 \mathrm{~mm}$ co-generated with greater than $60 \mathrm{~mm}$ ) or was generated as a result of testing material/fuels that would (or could) meet the definition of debris waste as defined in 40 CFR 268.2. Non-debris material/waste other than that noted above will be segregated from debris waste. ${ }^{(5)}$

TRU debris waste also is generated during cleanup, maintenance, or decontamination of the FMF glovebox(s) and laboratory hoods/benches.

\section{WASTE MATRIX CODE}

The definitions of waste matrix codes are obtained from the DOE Waste Treatability Group Guidance. ${ }^{(16)}$ The waste to be shipped to AMWTP is comprised of heterogeneous inorganic and organic debris. The TRU debris waste generated from MFC AL and FMF glovebox/hot cell operations are classified under the WIPP program as follows:

- $\quad$ Summary Category Group: S5000

- Waste Matrix Code Group: Heterogeneous Debris Waste

- Waste Matrix Code: S5490, Unknown/Other Heterogeneous Debris.

This final category includes waste that is consistent with the definition of the Heterogeneous Debris (S5400) summary category, but does not meet the criteria for assignment into the S5410, S5420, S5440, S5450, or S5460 specific-detailed categories.

\section{RADIOLOGICAL CHARACTERIZATION}

The ten WIPP-tracked radionuclides are indicated with asterisks in Table 2. The two most prevalent isotopes in the waste, based on the highest activities reported, are ${ }^{238} \mathrm{Pu}$ and ${ }^{241} \mathrm{Pu}$. Because of the variety of radionuclides used as feed to the various projects conducted at MFC, the radionuclide waste constituents and their activities expected in each container are variable.

The isotopic composition and ranges of MFC waste were determined based on the IWTS Material and Waste Characterization Profiles for the waste identified in Table 1. Multiple sources (i.e., Lawrence Livermore National Laboratory, Los Alamos National Laboratory) of the radionuclides, and therefore multiple compositions (e.g., weapons grade, heat source, and reactor grade) of the feed materials used in the various processes conducted at MFC, make it difficult to estimate a single ratio for all of the waste generated.

Legacy material generated from plutonium sent from Lawrence Livermore National Laboratory was used as feed material in the Casting Laboratory glovebox and FMF in support of the Integral Fast Reactor and AFCI. The feed material was identified as weapons-grade or reactor-grade plutonium from several Lawrence Livermore National Laboratory projects (i.e., defense-related) and processing (dismantlement) of special pits from Rocky Flats Plant. ${ }^{(6)}$

Plutonium feedstock used to make plutonium-zirconium alloys have the approximate isotopic composition in atom percent of $0.04 \%{ }^{238} \mathrm{Pu}, 65.2 \%{ }^{239} \mathrm{Pu}, 13.0 \%{ }^{240} \mathrm{Pu}, 0.45 \%{ }^{241} \mathrm{Pu}, 0.27 \%{ }^{242} \mathrm{Pu}$, and $21 \%{ }^{241} \mathrm{Am}$. The americium-bearing alloy is fabricated from $\mathrm{Pu}-20$-Am feedstock with the same composition. ${ }^{(18)}$ 
Containers shipped to AMWTP will be assayed to verify the MFC-reported radionuclide data, which were based on material balance, smear analysis, and destructive or non-destructive assay data generated prior to shipment. Table 2 provides a summary of potential radionuclides and concentration ranges that may be found in MFC debris waste.

Table 2. Radionuclide content range. $(7,8,9,10,11,12,13,14,15,38,39)$

\begin{tabular}{|c|c|c|}
\hline Radionuclide & Low (nCi/g) & $\operatorname{High}(\mathrm{nCi} / \mathrm{g})$ \\
\hline${ }^{241} \mathrm{Am} *$ & $0.00 \mathrm{E}+00$ & $8.00 \mathrm{E}+06$ \\
\hline${ }^{243} \mathrm{Am}$ & $0.00 \mathrm{E}+00$ & $3.00 \mathrm{E}+04$ \\
\hline${ }^{137 m} \mathrm{Ba}$ & $0.00 \mathrm{E}+00$ & $1.50 \mathrm{E}+02$ \\
\hline${ }^{144} \mathrm{Ce}$ & $0.00 \mathrm{E}+00$ & $1.00 \mathrm{E}+01$ \\
\hline${ }^{58} \mathrm{Co}$ & $0.00 \mathrm{E}+00$ & $1.00 \mathrm{E}-02$ \\
\hline${ }^{60} \mathrm{Co}$ & $0.00 \mathrm{E}+00$ & $1.10 \mathrm{E}+02$ \\
\hline${ }^{134} \mathrm{Cs}$ & $0.00 \mathrm{E}+00$ & $1.00 \mathrm{E}-02$ \\
\hline${ }^{137} \mathrm{Cs}^{*}$ & $0.00 \mathrm{E}+00$ & $1.00 \mathrm{E}+01$ \\
\hline${ }^{154} \mathrm{Eu}$ & $0.00 \mathrm{E}+00$ & $1.00 \mathrm{E}+01$ \\
\hline${ }^{155} \mathrm{Eu}$ & $0.00 \mathrm{E}+00$ & $1.00 \mathrm{E}+01$ \\
\hline${ }^{55} \mathrm{Fe}$ & $0.00 \mathrm{E}+00$ & $1.00 \mathrm{E}-02$ \\
\hline${ }^{54} \mathrm{Mn}$ & $0.00 \mathrm{E}+00$ & $1.00 \mathrm{E}+01$ \\
\hline${ }^{95} \mathrm{Nb}$ & $0.00 \mathrm{E}+00$ & $1.00 \mathrm{E}-02$ \\
\hline${ }^{237} \mathrm{~Np}$ & $0.00 \mathrm{E}+00$ & $8.00 \mathrm{E}+03$ \\
\hline${ }^{147} \mathrm{Pm}$ & $0.00 \mathrm{E}+00$ & $1.00 \mathrm{E}-02$ \\
\hline${ }^{144} \mathrm{Pr}$ & $0.00 \mathrm{E}+00$ & $1.00 \mathrm{E}-02$ \\
\hline${ }^{144 \mathrm{~m}} \mathrm{Pr}$ & $0.00 \mathrm{E}+00$ & $1.00 \mathrm{E}-02$ \\
\hline${ }^{238} \mathrm{Pu}^{*}$ & $0.00 \mathrm{E}+00$ & $9.42 \mathrm{E}+06$ \\
\hline${ }^{239} \mathrm{Pu}^{*}$ & $0.00 \mathrm{E}+00$ & $5.70 \mathrm{E}+05$ \\
\hline${ }^{240} \mathrm{Pu}^{*}$ & $0.00 \mathrm{E}+00$ & $8.00 \mathrm{E}+04$ \\
\hline${ }^{241} \mathrm{Pu}$ & $0.00 \mathrm{E}+00$ & $1.11 \mathrm{E}+06$ \\
\hline${ }^{242} \mathrm{Pu}^{*}$ & $0.00 \mathrm{E}+00$ & $1.60 \mathrm{E}+01$ \\
\hline${ }^{244} \mathrm{Pu}$ & $0.00 \mathrm{E}+00$ & $3.00 \mathrm{E}+01$ \\
\hline${ }^{106} \mathrm{Rh}$ & $0.00 \mathrm{E}+00$ & $1.00 \mathrm{E}+01$ \\
\hline${ }^{106} \mathrm{Ru}$ & $0.00 \mathrm{E}+00$ & $1.00 \mathrm{E}+01$ \\
\hline${ }^{125} \mathrm{Sb}$ & $0.00 \mathrm{E}+00$ & $1.50 \mathrm{E}+01$ \\
\hline${ }^{90} \mathrm{Sr}^{*}$ & $0.00 \mathrm{E}+00$ & $1.00 \mathrm{E}+01$ \\
\hline${ }^{230} \mathrm{Th}$ & $0.00 \mathrm{E}+00$ & $6.00 \mathrm{E}-01$ \\
\hline${ }^{232} \mathrm{Th}$ & $0.00 \mathrm{E}+00$ & $6.00 \mathrm{E}+00$ \\
\hline${ }^{233} \mathrm{U}^{*}$ & $0.00 \mathrm{E}+00$ & $1.00 \mathrm{E}+03$ \\
\hline${ }^{234} \mathrm{U}^{*}$ & $0.00 \mathrm{E}+00$ & $2.50 \mathrm{E}+02$ \\
\hline${ }^{235} \mathrm{U}$ & $0.00 \mathrm{E}+00$ & $1.00 \mathrm{E}+01$ \\
\hline${ }^{236} \mathrm{U}$ & $0.00 \mathrm{E}+00$ & $2.50 \mathrm{E}+02$ \\
\hline${ }^{238} \mathrm{U}^{*}$ & $0.00 \mathrm{E}+00$ & $1.00 \mathrm{E}+02$ \\
\hline
\end{tabular}


Table 2. (continued).

\begin{tabular}{|c|c|c|}
\hline Radionuclide & Low $(\mathrm{nCi} / \mathrm{g})$ & High $(\mathrm{nCi} / \mathrm{g})$ \\
\hline${ }^{90} \mathrm{Y}$ & $0.00 \mathrm{E}+00$ & $1.00 \mathrm{E}+01$ \\
\hline${ }^{95} \mathrm{Zr}$ & $0.00 \mathrm{E}+00$ & $1.00 \mathrm{E}-02$ \\
\hline
\end{tabular}

*The ten WIPP-tracked radionuclides.

\section{WASTE MATERIAL INPUTS}

Waste material inputs and their origin for MFC TRU debris waste from Buildings 752 and 704 to be shipped to AMWTP are identified in Table 3.

Table 3. Waste chemicals/constituents in Materials and Fuels Complex transuranic debris. ${ }^{(5,9,11,13,14,15)}$

\begin{tabular}{|l|c|c|l|}
\hline $\begin{array}{c}\text { Waste } \\
\text { Chemicals/Constituents }\end{array}$ & CAS & Origin & \multicolumn{1}{|c|}{ Where found } \\
\hline Cadmium & $7440-43-9$ & AL, FMF & $\begin{array}{l}\text { Electrical components, FCF } \\
\text { electrorefining salts, filter frames }\end{array}$ \\
\hline Chromium & $7440-47-3$ & AL, FMF & $\begin{array}{l}\text { Electrical components, etching solutions } \\
\text { from stainless steel analysis (e.g. fuel } \\
\text { cladding), refurbishment (e.g., paint), } \\
\text { FCF electrorefining salts }\end{array}$ \\
\hline Lead & $7439-92-1$ & AL, FMF & $\begin{array}{l}\text { Lead-lined gloves, shielding, } \\
\text { refurbishment (e.g., paint), brass } \\
\text { fittings/valves }\end{array}$ \\
\hline Silver & $7440-22-4$ & AL, FMF & $\begin{array}{l}\text { Electrical components, refurbishment } \\
\text { (e.g., paint) }\end{array}$ \\
\hline
\end{tabular}

Additional materials used in Buildings 704 and 752 laboratory hoods/benches, gloveboxes, and hot cells that may be part of the debris waste include the following:

- $\quad$ Neutralized, absorbed nitric acid, hydrochloric acid, or hydrofluoric acid; used in dissolution of fuels and other materials during experimentation and sample preparation ${ }^{(22,37)}$

- $\quad$ Absorbents such as Oil Dri, Aquaset II, kitty litter, diatomaceous earth, and Petroset II; used to immobilize liquids ${ }^{(7,10)}$

- Additional metals may be present in metal components described in Section 4.3, including barium, beryllium, calcium, cobalt, copper, iron, lithium, manganese, nickel, uranium, vanadium, zinc and zirconium.

- $\quad$ Solvents acetone, propanol and methanol ${ }^{(7,8,9,10,11,12,13,14,15,38,39,40)}$

- Cleaning solutions: Blue Windex, Fantastic All Purpose Cleaner Extreme Simple Green, Radiacwash I and II ${ }^{(5,28,32,33,34,35)}$; used during clean-up/decontamination of gloveboxes, laboratory bench tops (hoods), and hot cells. 


\section{RESOURCE CONSERVATION AND RECOVERY ACT DETERMINATIONS}

Characterization is performed by MFC through individual IWTS profiles that document actual waste stream and container content. These profiles are reviewed and modified as necessary to ensure adequate characterization prior to shipment. At a minimum, the profiles are updated when new waste processes are generating waste and contributing waste to AMWTP's inventory, new HWNs are identified, or changes to the primary contributing radioisotopes occurs. The following subsections identify the HWNs associated with MFC TRU debris. ${ }^{(9,11,13,14,15)}$

\subsection{Ignitables, Corrosives, and Reactives}

Ignitable, corrosive, and reactive waste will not be shipped to AMWTP. Waste with potential ignitable, corrosive, or reactive properties are treated (i.e., liquids neutralized and absorbed and sodium/sodium-potassium reacted) prior to waste container closure. ${ }^{(4,5)}$

\subsection{Toxicity Characteristic Leachate Procedure}

MFC debris waste listed in Table 1 may contain characteristic hazardous waste as identified in Table 3. Applicable Environmental Protection Agency HWNs are based on process knowledge, up-to-date MFC IWTS material and characterization profiles, and analytical results. The MFC mixed-TRU debris waste to be sent to AMWTP will be profiled with the toxicity characteristic HWNs, D006, D007, D008, and D011. ${ }^{(9,11,13,14,15)}$ HWN D005 is not assigned to this waste stream since barium is not present at or above the regulatory level based on process knowledge and on the IWTS profiles in Table 1. ${ }^{(7,8,9,10,11,12,13,14,15,38,39)}$

\subsection{Listed Waste (F, P, U, and K)}

The MFC TRU debris waste shipped to AMWTP is not contaminated with F001, F002, F004, and F005 spent solvent constituents or associated with cyanide electroplating operations (or contaminated with electroplating waste) that would result in the assignment of the F006, F007, F008, or F009 HWNs. The waste may contain F003 solvents (i.e., acetone, methanol), but the debris waste is not ignitable and

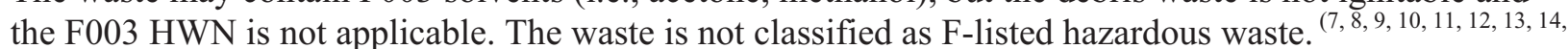
$15,38,39)$

The MFC TRU debris waste to be shipped to AMWTP does not contain discarded, unused, commercial chemical products; off-specification species; a manufacturing intermediate; or contain spill residues thereof that would meet the listing of P or U-listed hazardous waste as identified in $40 \mathrm{CFR}$ 261.33.

Hydrofluoric acid is used at MFC in fuel dissolution and other laboratory sample analysis processes. Sample waste is neutralized and stabilized before packaging. No free liquids are allowed and no hydrofluoric acid remains at the end of the analysis. This waste stream was not mixed with, does not contain, and was not derived from an unused commercial chemical product, an off-specification species thereof, or a manufacturing intermediate nor does it contain spill residues thereof that would be classified as a U134 HWN. Based on this information, the U134 HWN is not assigned to MFC waste streams. 
Beryllium is a contaminant associated with this waste. The source of the beryllium is not associated with a powdered form and is not associated with unused commercial chemical product, an off-specification species, or a container residue nor does it contain a spill residue thereof. Therefore, the P015 HWN for beryllium is not assigned to MFC waste streams. ${ }^{(5,7,8,9,10,11,12,13,14,15,38,39)}$

The MFC TRU debris waste is not hazardous waste from specific sources listed in 40 CFR 261.32 (i.e., K-listed hazardous waste) and they have not been mixed with, derived from the treatment of K-listed wastes, or contain spill residues thereof. The waste materials in this waste stream are not assigned K-listed HWNs. ${ }^{(7,8,9,10,11,12,13,14,15,38,39)}$

\section{TOXIC SUBSTANCES CONTROL ACT POLYCHLORINATED BIPHENYLS DETERMINATIONS}

Polychlorinated biphenyls are not used in any of the processes and are not present in any of the MFC waste. Polychlorinated biphenyls contaminated debris waste will not be shipped to AMWTP. ${ }^{(5,7,8,9 \text {, }}$ $10,11,12,13,14,15,38,39)$

\section{PROHIBITED ITEMS}

Segregation practices for MFC debris prevent inclusion of the following prohibited items from being placed into TRU debris waste containers and subsequently shipped to AMWTP: ${ }^{(4,5)}$

- Waste that has ever been managed as high-level waste

- $\quad$ Sealed containers greater than $4 \mathrm{~L}$

- Hazardous waste not occurring as co-contaminants with TRU mixed waste

- $\quad$ Non-radionuclide pyrophoric materials

- Non-debris waste unrelated to the generating processes associated with the debris waste stream or not inherently commingled with the debris waste

- Waste containing elemental mercury

- Waste containing polychlorinated biphenyls

- $\quad$ Non-defense-related waste that is not inherently commingled with defense-related waste

- Waste managed as non-TRU

- Waste containing pressurized containers/compressed gases/aerosol cans

- Waste with any amounts of liquids

- $\quad$ Corrosive waste

- Ignitable waste

- $\quad$ Reactive, pyrophoric, shock sensitive, explosives, and unstable waste 
- Waste not in conformance with the AMWTP waste stream profile (i.e., Form 1687)

- Waste that is shielded

- $\quad$ Containers with poor integrity

- Incompatible waste within the same container

- Waste with fissile gram equivalents greater than 200 value.

\section{WASTE PACKAGING}

Contact-handled TRU waste sent to AMWTP under the MFC Transport Plan may be packaged without using approved TRUCON limits. The waste will be shipped in compliance with the AMWTP waste acceptance criteria or other approved documented limits (such as ET-021-09 ${ }^{(24)}$ ) and will be authorized by citing an approval issued by AMWTP prior to packaging waste. TRU isotope-bearing liquids, including aqueous solutions from acid dissolution, sample preparation, or decontamination operations, or contaminated oil (such as vacuum pump oil) were previously generated and placed in legacy waste containers. Liquids are neutralized (if applicable) and treated with absorbent material (i.e., Aquaset, Petroset, or diatomaceous earth) to ensure no free liquids remain in the waste. Homogenous solid waste is typically bagged out of gloveboxes and packaged together in a campaign basis, based on radionuclide content.

Waste shipped to AMWTP will be packaged and shipped in accordance with the DOE Order 435.1, LWP-8300, "Transuranic Waste Handling," MP-TRUW-8.40, "INL Non-AMWTP Radioactive or Mixed Waste Acceptance," PLN-8300, "MFC CH-TRU Waste Certification Program Plan," and ET-021-09 Letter from E. Torres to R. P. Grant re Materials and Fuels Complex Packaging Configuration. ${ }^{(1,4,23,24)}$

Waste shipped to AMWTP is packaged as follows $:^{(1,4,5,23,24,25)}$

1. The MFC debris container dose rate target is less than $125 \mathrm{mR} / \mathrm{hr}$ at contact ${ }^{(24)}$, with no internal items exceeding $200 \mathrm{mR} / \mathrm{hr}$. Individual items inside the container with dose rates approaching or exceeding $200 \mathrm{mR} / \mathrm{hr}$ will be placed against the wall of the receiving container in a manner that ensures the item will remain where it was placed until the container is closed and the surface dose measurement is performed. The external container surface must be less than $200 \mathrm{mR} / \mathrm{hr}$ on contact. Containers using this configuration must be identified prior to shipment. The placement location of these items will be identified for subsequent AMWTP processing verification.

2. Waste is bagged (singly or doubly, dependent on waste) out of a glovebox or hot cell through a port and bagged into a poly sleeve; bag/sleeve is closed and placed into a container (e.g., cans [1-qt to 2-gal paint cans] or drums [5-gal to 55-gal drum]) and vented appropriately.

3. Bulky or heavy items are blocked or braced inside the waste containers.

4. Surface contamination on outer waste containers will be less than $200 \mathrm{dpm} / 100 \mathrm{~cm}^{2}$ beta-gamma and less than $20 \mathrm{dpm} / 100 \mathrm{~cm}^{2}$ alpha.

5. Inner containers (i.e., paint cans and small drums) with volumes greater than $4 \mathrm{~L}$ are punctured, vented, or have a blocked open relief valve.

6. Waste is packaged in one of the following standard containers: 
a. Department of Transportation 7A, Type A, 55-gal drum

b. Department of Transportation 7A, Type A, TRU Package Transporter Model 2 (TRUPACT-II) Standard Waste Box.

7. TRU waste containers are vented with the drum liner (if present) punctured or have filter vents.

8. The same container or pallet does not contain incompatible waste.

9. The waste does not contain residual free liquids, but may contain absorbed radioactive fluids that will remain immobile during packaging, handling, transport, storage, and disposal.

10. The methods of closure for plastic bags greater than $4 \mathrm{~L}$ used for waste confinement is as follows:
a. Twist and tape closure
b. Fold and tape closure
c. Heat-seal closure or twist and tape closure with a minimum of one filter vent.

\section{REFERENCES}

1. MFC CH-TRU Waste Certification Program Plan, 10/27/2008, PLN-8300 [P675A].

2. Advanced Fuel Cycle Initiative (AFCI) Program Plan, DOE Office of Nuclear Energy, 5/1/2005, Draft $[\mathrm{P} 676 \mathrm{~S}]$.

3. The Defense Programs Origin of Transuranic Waste at Argonne National Laboratory-West, H. F. McFarlane, 11/1/2001 (ANL-NT-192) [P679A].

4. Transuranic Waste Handling, Idaho National Laboratory, 10/27/08 LWP-8300 [P682S].

5. Idaho National Laboratory General Facility Waste, FMF-01-015, Rev. 3, 11/3/08.

6. Interview of Roger Haga, MFC Safeguards, Re: Traceability of Defense Materials to Casting Laboratory and Analytical Laboratory, Scott Smith and Dave Guerin, 8/31/2005 [C554S].

7. IWTS Material Profile No. 3527: Analytical Lab TRU Waste Generated from ANL Bldg 752 Analytical Laboratory, IWTS, 5/19/2008 [P708A].

8. IWTS Material Profile No. 5274N: Misc. Waste from Waste Form Testing, Alpha, \& Special Projects Glovebox. Etc., ANL 752 Analytical Laboratory, IWTS, 5/19/2008 (IWTS 5274N) [P716A].

9. IWTS Material Profile No. ANL503T: HEPA Filters Contaminated with Characteristic Waste and TRU, IWTS, 2/18/1998 [P734A].

10. IWTS Material Profile No. 3526: Casting Lab TRU Waste, generated from the ANL Bldg. 752 Analytical Laboratory - Inactive, IWTS, 1/28/2008 [P709A]. 
11. IWTS Material Profile No. 3657P: Analytical Laboratory (Including Casting Lab) Mixed Transuranic Waste - Inactive (04/02/2007), IWTS, 12/3/2002 (IWTS 3657P) [P710A].

12. IWTS Material Profile No. 5419N: LL TRU, $>100 \mathrm{nCi} / \mathrm{g}$ Generated from ANL-704: ANL Bldg 704, Fuel Manufacturing Facility, IWTS, 5/19/2008 (IWTS 5419N) [P715A].

13. IWTS Material Profile No. 5185N: Casting Lab Pb Lined Gloves, Generated from the Bldg. 752, Analytical Laboratory, IWTS, 5/19/2008 (IWTS 5185N) [P718A].

14. IWTS Material and Characterization Profile No. ANL142T: Lead Contaminated Articles and Debris - TRU Contaminated - Inactive, IWTS, 2/13/1998 [P750A].

15. IWTS Material and Characterization Profile No. ANL505T: Debris Contaminated with Characteristic Waste and MTRU - Inactive, IWTS, 2/18/1998 [P751A].

16. DOE Waste Treatability Group Guidance, T. D. Kirkpatrick, January 1995 (DOE/LLW-217, Rev. 0) [P670A].

17. Accelerator Transmutation of Waste Project Arc-Melting Activities, R. J. Kennedy and D. D. Standfield, 6/8/2001 (W0650-0049-EP) [P719S].

18. Fabrication and Characterization of Futurix $\mathrm{Pu}, \mathrm{Np}$ and Am-Bearing Metallic Alloy Fuel Slugs, D. Porter and D. D. Peay, 8/9/2005 (W0650-0054-OP) [P721S].

19. Accelerator Transmutation of Waste Project Thermal Analysis Studies on ATW-1 Samples in Analytical Laboratory, J. R. Kennedy and D. D. Standfield, 7/31/2002 (W0660-0078-AP) [P703A].

20. Accelerator Transmutation of Waste Project Diffusion Couple FCCI Studies on ATW, J. R. Kennedy and D. D. Standfield, 7/18/2002 (W0660-0076-AP) [P724A].

21. Determination of Isotopic Composition of Uranium and Plutonium Using Finnigan Mat 262 Thermal Ionization Mass Spectrometer, M. Michlik and D. Standfield, 5/7/2001 (W0630-0041-KP) [P684S].

22. Fabrication and Characterization of $\mathrm{Pu}, \mathrm{Np}$, and Am-Bearing Metallic Alloy Specimens, MFC, 8/2/2005 (W0650-0070-OP) [P699A].

23. MP-TRUW-8.40, Rev. 6, INL Non-AMWTP Radioactive or Mixed Waste Acceptance, 3/9/2009.

24. Letter, E. Torres to R. P. Grant, "Materials and Fuels Complex Packaging Configuration - ET-02109", April 1, 2009.

25. General Laboratory Waste, MFC, 6/30/2005 (W0660-0035-AP) [P700S].

26. Determination of Gallium in Plutonium Oxide by Inductively-Coupled-Plasma Mass Spectrometer, MFC, 3/26/2003 (W0650-0064-KP) [P697S].

27. Determination of Boron in Plutonium Oxide by Inductively-Coupled-Plasma Atomic Emission Spectrometry, D. Cummings and D. D. Standfield, 3/26/2003 (W0650-0065-KP [P698S].

28. Idaho National Laboratory Contact-Handled Transuranic Waste Handling, AL-5000-LI-003, Rev. 0, 8/19/08. 
29. Reserved

30. Casting Laboratory Glovebox Thermolyne-21135 Model Furnace, MFC, 10/1/2002 (W06500058OP) [P693S].

31. Casting Laboratory AAA Cladding Tube Loading/Welding, R. Fielding and D. D. Standfield, 4/23/1993 (W0650-0059-OP) [P694S].

32. MSDS Blue Windex, S. C. Johnson Wax, 7/7/1993 [P704S].

33. MSDS Fantastik All Purpose Cleaner, National Brands Inc., 7/19/1990 [P705S].

34. MSDS Radiacwash I, Atomic Products Corp, 2/22/1988 [P706S].

35. MSDS Radiacwash II, Atomic Products Corp, 2/22/1988 [P707S].

36. Glovebox Bagout Bag Replacement and Waste/Material Bagout, MFC, 7/19/2005 (W0650-0008OP) [P689A].

37. Dissolution of Pu Metal, 5/22/2001 (W0630-0026-KP) [P683S]

38. IWTS Material Profile No. 5274N.R1: Misc. Waste from Waste Form Testing, Alpha, \& Special Projects Glovebox. Etc., ANL 752 Analytical Laboratory, IWTS, 9/29/09 (IWTS 5274N.R1).

39. IWTS Material Profile No. 3527.R1: Misc. Waste from Waste Form Testing, Alpha, \& Special Projects Glovebox. Etc., ANL 752 Analytical Laboratory, IWTS, 9/29/09 (IWTS 3527.R1).

40. Sample Preparation In The Waste Form Testing Glovebox in MFC-AL, MFC, 12/23/2009 (AL1500-LI-001). 